Ciência eNatura, Santa Maria, v. 37 Part 1 2015, p. 407-416

ISSN impressa: 0100-8307 ISSN on-line: 2179-460X

\title{
Investigating the Effects of Authentic Leadership of Managers on Organizational Commitment of Teachers with Organizational Justice as the Mediator Variable
}

\author{
Mohsen Alinezhad ${ }^{1}$, Hosein Abbasian², Mohammad Reza Behrangi ${ }^{3}$
}

\begin{abstract}
${ }^{1}$ M.A. student of educational management at the faculty of management, Kharazmi University, Tehran ${ }^{2}$ Assistant professor of educational management at the faculty of management, Kharazmi University, Tehran

${ }^{3}$ Associated professor of educational management at the faculty of management, Kharazmi University, Tehran
\end{abstract}

\begin{abstract}
The present study was conducted by the aim of investigating the fit of the presented model for the relationship between authentic leadership and organizational commitment of staff with a mediating role of organizational justice. The population of the research included all the teachers in high schools (for male students) in Education district 2 in Qom city. From the population, 300 individuals were selected through cluster sampling. For gathering the data, authentic leadership questionnaire (Avolio et al., 2007), organizational justice questionnaire of Niehoff E Moorman (1993), and Allen \& Meyer's Organizational Commitment Questionnaire (2002) were used. For analyzing the data, structural equation modeling - fit indices and path coefficients - was used. The results of the analysis showed that authentic leadership has a direct and significant effect on the organizational commitment of teachers. Also, authentic leadership has an indirect effect, through organizational justice, on organizational commitment. The other finding of the research is that organizational justice has a direct and significant effect on organizational commitment of teachers, and the offered conceptual model has a significant statistical fit, that means the explanatory model for organizational commitment based on authentic leadership and organizational justice has fitness with empirical data. Finally, based on the information obtained from structural equations model, it can also be said that all the components existing in the 3 variables of the research have positive and significant relationships with one another.
\end{abstract}

Keywords: Authentic Leadership, Organizational Commitment, Organizational Justice, structural equations model 


\section{Introduction}

Human Resources are considered as one of the most valuable organizational assets, the most important competitive advantage, and also the rarest source in the knowledge-based economy (Belcourt et al., 2008). Commitment of the people to organization leads to such important results as reduced mobility, increased motivation and organizational citizenship behavior, as well as social support; so organizations are looking for committed work force (Kwon and Banks, 2004).

Allen and Meyer published more than 15 research on organizational commitment since 1984 have contributed much in the field. They assume organizational commitment as an attitude and a mental state which expresses a willingness, a need, and a requirement for continued employment in an organization. Willingness is a real wanting to continue working in the organization; need is implies that people have to serve in the organization due to their investments there; and requirement implies a responsibility to organization to stay therein (in Klein et al., 2012)

Allen and Meyer developed a tri-dimensional model based on the observed similarities and differences in the definitions of organizational commitment (Meyer and Hersekovic, 2001). The three dimensions of organizational commitment are as follows:

1. Emotional commitment, an emotional dependence and a sense of identity and involvement of employees in the organization;

2. Continued commitment, including a person's willingness to stay in organization, reflecting the costs of leaving it against the benefits of staying with it.

3. Normative commitment, including the obligation to remain in the organization. This makes the employees remain in the organization after commitment and have a sense of loyalty or duty, and also feel that they are doing right (Allen and Meyer, 1991).
Klein et al. have defined commitment as a psychological bond that is based on one's goals. They considered commitment as a process and developed a model for it. Their process model shows four primary mode immediately determining commitment and a separate set of adjustments based on their levels contributing the increased commitment. The two immediate consequences of commitment (ie, motivation and persistence) contributing functionally in the final result are also shown (Klein and Park, 2015).

Many theories regarding leadership have been proposed by different schools (Ghasemi, 1388; Atkinson and Pilgrin, 2011; Tilstera, 2010), yet despite the interest in effective leadership, no favorite leadership style has been used. Thus, the researchers have paid attention to correct behaviors which can develop effective leaders (Avolio and Gardner, 2005). This gradually led to a new theory of authentic leadership by Avolio and Gardner. According to Avolio (2004), authentic leadership is the original root and framework of different forms of leadership. In fact, authentic leadership is composed of a charismatic leadership, transformational leadership, knowledgeable leadership, moral leadership, interactive leadership, direct leadership, and participating leadership and involves a high degree of ethics, respect, and positive tendencies of the leader. An authentic leader is defined as a person who is trustworthy, hopeful, optimist and the cognitively flexible.

The concept of authentic leadership originates from socio-psychological research in the field of authenticithy. From the ontological perspective, the authenticity reflects one's functions and actual core of their daily activities (Goldman and Kurnis, 2002). The Merriam-Webster dictionary defines authenticity as follows:

1. worthy of acceptance or belief as conforming to or based on fact

2. conforming to an original so as to reproduce essential features

3. made or done the same way as an original 
4. not false or imitation

5. true to one's own personality, spirit, or character (in Stewart, 2012)

Walumbwa et al. (2008) identified four elements to develop and validation of the authentic leadership:

1. Self-awareness refers to demonstrating an understanding of how one derives

and makes meaning of the world.

2. Balanced processing refers to leaders who show that they objectively analyze all relevant data before coming to a decision.

3. Relational transparency refers to presenting one's authentic self (as opposed to a fake or distorted self) to others.

4. internalized moral perspective refers to an internalized and integrated form of self-regulation which is guided by internal moral standards and values

In addition to leadership, organizational commitment has been shown by studies to be affected by the variable organizational justice (Crow et al., 2011). Research has been carried out on the psychological mechanisms of organizational justice in relation to the people's judgment about fairness, and their perceptions of the concepts. When employees feel they are treated justly, they tend to show a high job performance, better work attitude, and lower levels of stress (Cropanzana and Molina, 2015).

Many people believe that organizational justice must be created by the organization's managers and authorities. This means to improve integrity, honesty, loyalty, and trust (interactional justice) in the organization through proper distribution of resources, opportunities and rewards to employees (distributive justice) using procedures, guidelines, tools and appropriate ways of allocating these resources (procedural justice) to establish appropriate relations between individuals and employees and improve the perceived fairness of the staff in order to improve performance, effectiveness and efficiency of the organization as a whole (Philip et al., 2012).

Organizational Justice through the three dimensions is as follows:

Distributive justice: this dimension of justice refers to fairness of outcomes and results that employees receive such as cash payment or rewards and promotions in organization (Gelens et al., 2013).

Procedural justice: this dimension of justice originates from perceived fairness out of organizational policies and procedures and determines the allocation of resources and other management decisions (Elamin and Alomaim, 2011).

Interactional justice: this kind of justice is associated with cognitive, emotional, and behavioral responses related to the management or the supervisor (Charash and Spector, 2001). In short, interactional justice refers to the perception of fairness in the interpersonal behaviors (Karriker \& Williams, 2009).

Given the above facts and the correlation between variables (authentic leadership, organizational commitment, and organizational justice), the present study seeks to answer the question "does the authentic leadership with the mediator variable affect the organizational commitment?" and whether the conceptual model presented in the study is significant. 


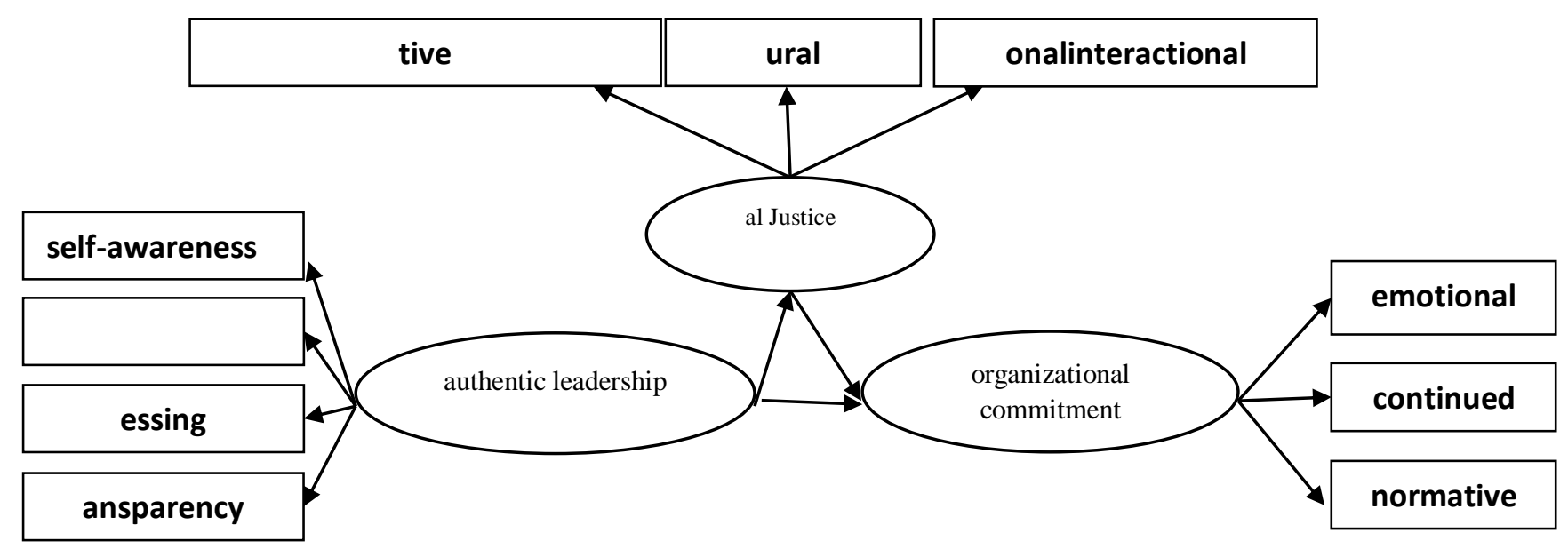

\section{Methodology}

The present study is a description of correlation of causative pattern-finding type. The population consists of all male high school teachers in $2^{\text {nd }}$ area of education in the city of Qom. The number includes 686 persons. The population of above 400 were selected by cluster sampling. Firstly, among all high schools in the city of Qom, the $2^{\text {nd }}$ area and then 14 high schools were selected randomly and all their teachers were evaluated. Finally, after collecting the questionnaires distributed among teachers and ignoring incomplete questionnaires, 300 were entered into the final analysis. To gather information and assess the authentic leadership, the questionnaire Avolio et al. (2007) was used, which includes four functional dimensions, namely self-awareness, balanced processing, moral aspect and relational transparency. To measure organizational commitment, the questionnaire of organizational commitment by Allen \& Meyer (2002) with18 items was used. The questionnaire is a revised form of the 24item questionnaire for organizational commitment by Allen \& Meyer (1991). The credit of report by Meyer and Allen for each of the components of organizational commitment is $0.87,0.75$, and 0.79 for emotional commitment, continued commitment, and normative commitment, respectively. In order to measure the third variable, the organizational justice questionnaire by Nihoff and Moorman (1993) which consists of three parts, each one measuring distributive justice, procedural justice and interactional justice- was used. The validity of organizational justice questionnaire was reported by Shokrkon and No'ami to be 0.80 . They also reported its reliability, using Cronbach's alpha coefficient to be 0.73 . Validity of the tool has been approved by all research professionals and experts. Finally, to analyze the data obtained in this study, the softwares SPSS and AMOS have been used, and data applied in two descriptive levels with diagrams, frequency distribution tables, percentages related to demographic characteristics, and descriptive statistics to investigate variables of the sample. In the inferential level, in accordance with the measured data and statistical assumptions, fitting parameters and course coefficients were used to test the hypotheses.

\section{Findings}

The demographic characteristics of the type of employment were as follows:

Official: $86.7 \%$, contractor: $10.8 \%$, and temporal: $3.3 \%$. Among them, 3.4\% were between 20 to 30 years, $33 \%$ between 31 to 40 years, $46.3 \%$ between 41 to 50 years, and $16.3 \%$ were over 50 years. $3 \%$ were high school diploma, $5.7 \%$ were 
undergraduates, $61.7 \%$ had B.A, and $29.7 \%$ had

M.A.

Table 1.

\begin{tabular}{cccc}
\hline Statistical Index Scale & No & Mean & SD \\
\hline Self-awareness & 300 & 13.46 & 3.55 \\
Balanced processing & 300 & 10.19 & 2.77 \\
Internalized moral perspective & 300 & 12.99 & 3.85 \\
Relational transparency & 300 & 15.65 & 4.51 \\
Distributive justice & 300 & 12.08 & 3.85 \\
Procedural justice & 300 & 14.84 & 7.01 \\
Interactional justice & 300 & 22.08 & 8.03 \\
Emotional commitment & 300 & 17.73 & 2.91 \\
continued commitment & 300 & 15.27 & 3.13 \\
\hline normative commitment & 300 & 17.76 & 4.07 \\
\hline
\end{tabular}

As the results table shows, among the dimensions of authentic leadership the highest one is of relational transparency. In the organizational justice, interactional justice is the greatest. In organizational commitment, the normative commitment is highest. To verify whether the explanatory model for organizational commitment based on the authentic leadership and organizational justice fits with the experimental data, the software Amos and course analysis were applied. Authentic leadership affects significantly teacher's organizational commitment.

Table 2. Coefficients and significance of direct effects of authentic leadership on organizational commitment

\begin{tabular}{|c|c|c|c|c|c|c|}
\hline Criterion variable & $\begin{array}{l}\text { Predictor } \\
\text { variable }\end{array}$ & $\begin{array}{l}\text { Effect } \\
\text { type }\end{array}$ & $\begin{array}{c}\text { Non- } \\
\text { Standardized } \\
\text { coefficient }\end{array}$ & $\begin{array}{c}\text { Standardized } \\
\beta\end{array}$ & $\begin{array}{l}\text { Significance } \\
\text { statistics }\end{array}$ & sig \\
\hline $\begin{array}{c}\text { Organizational } \\
\text { commitment }\end{array}$ & $\begin{array}{l}\text { Authentic } \\
\text { leadership }\end{array}$ & Direct & 0.28 & 0.49 & 4.25 & 0.001 \\
\hline
\end{tabular}

As the results table shows, authentic leadership has a significant positive correlation with organizational commitment. Authentic leadership and a direct correlation with organizational commitment of the teachers is $t=$ $4 / 25$ and $\beta=0.49$. So the direct effect of authentic leadership on organizational commitment was confirmed with $95 \%$ confidence.

Authentic leadership has a significant effect on organizational commitment indirectly through organizational justice.

Table 3. Coefficients and significance of direct effects of organizational justice on organizational commitment

\begin{tabular}{cccccc}
\hline Criterion variable & $\begin{array}{c}\text { Predictor } \\
\text { variable }\end{array}$ & Effect type & $\begin{array}{c}\text { Non-Standardized } \\
\text { coefficient }\end{array}$ & $\begin{array}{c}\text { Standardized } \\
\beta\end{array}$ & $\begin{array}{c}\text { Significance } \\
\text { statistics }\end{array}$ \\
\hline $\begin{array}{c}\text { Organizational } \\
\text { commitment }\end{array}$ & $\begin{array}{c}\text { Religious } \\
\text { orientation }\end{array}$ & $\begin{array}{c}\text { Indirect (mediator } \\
\text { organizational } \\
\text { justice) }\end{array}$ & 0.12 & 0.35 & 2.11 \\
\hline
\end{tabular}


What can be drawn from the above results is that authentic leadership has a significant impact on organizational commitment indirectly through organizational justice. The indirect relationship between authentic leadership and organizational commitment of teachers is as follows: $t=2.11$ and $\beta=0.35$. The indirect effect of authentic leadership on organizational commitment is confirmed with $95 \%$ confidence. Organizational justice has a significant impact on organizational commitment of teachers

Table 4. Coefficients and significance of direct effects of organizational justice on organizational commitment

\begin{tabular}{cccccc}
\hline Criterion variable & Predictor variable & $\begin{array}{c}\text { Effect } \\
\text { type }\end{array}$ & $\begin{array}{c}\text { Non- } \\
\text { Standardized } \\
\text { coefficient }\end{array}$ & $\begin{array}{c}\text { Standardized } \\
\beta\end{array}$ & $\begin{array}{c}\text { Significance } \\
\text { statistics }\end{array}$ \\
\hline $\begin{array}{c}\text { Organizational } \\
\text { commitment }\end{array}$ & $\begin{array}{c}\text { Organizational } \\
\text { justice }\end{array}$ & Direct & 0.42 & 0.74 & 3.32 \\
\hline
\end{tabular}

What can be drawn from the above results is that organizational justice has a significant correlation with organizational commitment of teachers. The direct relationship between organizational justice and organizational commitment of teachers is as follows: $\mathrm{t}=3.32$ and $\beta=0.74$. Thus the direct effect of organizational justice on organizational commitment is confirmed with $95 \%$ confidence.

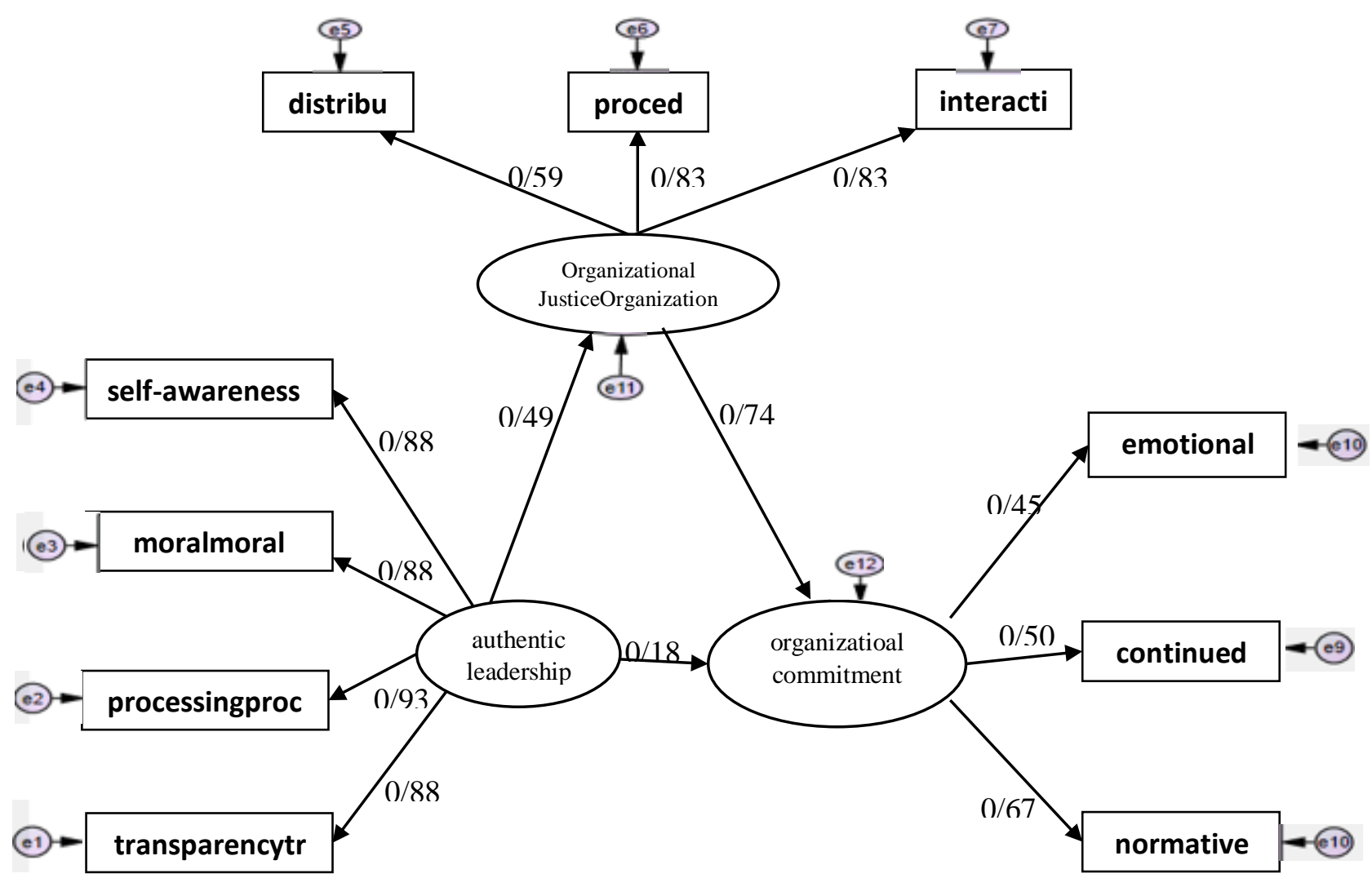

Diagram 1. Research model in standardized coefficients mode 
Table 5. Fit indices for research model course analysis

\begin{tabular}{|c|c|c|}
\hline \multirow{2}{*}{ Index } & \multicolumn{2}{|c|}{ Fit index } \\
\cline { 2 - 3 } & value & acceptable \\
\hline$\frac{\chi 2}{d f}$ & 2.21 & Less than 3 \\
\hline RMSEA & 0.09 & Less than 0.1 \\
\hline CFI & 0.94 & More than 0.09 \\
\hline NFI & 0.91 & More than 0.9 \\
\hline GFI & 0.93 & More than 0.9 \\
\hline AGFI & 0.89 & More than 0.9 \\
\hline
\end{tabular}

In general, in Amos program, each of the obtained indices does not represent by itself the fitness or lack of fitness of the model and these indices should be interpreted together. Values obtained for these indices show that the model enjoys an appropriate status for explanation and fitness.

\section{Discussion and Conclusion}

Assuming that authentic leadership is considered as a metaphor for professional and ethical effectiveness and an effective and informed way for educational management (Begley, 2001) with an effect on organizational commitment (Leroy, Palinsky and Simon, 2011), the findings of present study also show that authentic leadership has significant effects on organizational commitment and is consistent with the results of Chen (2010), Emuwa (2015) and Leroy et al. (2012).

Regarding the other research hypothesis that is organizational justice has a significant direct effect on organizational commitment of teachers, studies have shown that organizational commitment and is affected by the variable organizational justice (Crow et al., 2011). The relationship between organizational justice and commitment of people in the organization shows that any increase in organizational benefits will increase their commitment to integration of tasks and goals of the organization (Owliyaee, 1393). According to the results of Crow et al. (2011), Abdullahi et al
(1393), and Doosti et al (1392), these findings are also confirmed.

As previously mentioned, many believe that organizational justice should be organized by the managers and authorities of the organization (Philip et al., 2012). As authentic leaders have value-moral insights and are aware of the knowledge and abilities of others as well as the context of the organization (Gardner et al., 2011), it can contribute to the perception of organizational justice. Given the literature including Krish (2012) that represents a direct effect of authentic leadership on the employee's perceptions of justice, the hypothesis that authentic leadership has an indirect effect on organizational commitment of teachers through organizational justice is confirmed.

In general, a review of research literature confirms that the conceptual model has a significant fitness. This means that the model for explaining organizational commitment based on authentic leadership and organizational justice has fitness with the experimental data.

Given the results obtained as well as the correlation between these variables, it is recommended that school administrators should emphasize on all four dimensions the commitment of the staff to be increased. (selfawareness, balanced processing, relational transparency, and internalized moral perspective) in order for the staff to have increased organizational commitment. It is to say that 
- words and actions of the managers must be consistent;

- teachers should be encouraged to take decisions based on right and moral values;

- teachers should be encouraged to challenge the existing decisions, even if contrary to their beliefs; and

- interaction with members of the organization and relations should be clear.

By doing so, the school staff will be more committed.

\section{REFERENCES}

Owliyaee, Z. (1393). Exploring the relationship of four dimensions of organizational justice and organizational commitment among the staff of education in Tehran. M.A. thesis, Allame Tabataba'i University. (Persian)

Doosti, M., Amin Khatibi, and Ali-Asghar Khalili, (1392). The relationship between organizational justice and organizational commitment among the physical education organization of Mazandaran. Sports Management and Physical Sciences Research; year 3, 5: 59-71. (Persian)

Abdullahi, Bijan, Gholam-Ali Yusselyani, and Jamal Hatamian (1393). The relationship between organizational justice and organizational commitment in elementary school teachers. NEW THOUGHTS ON EDUCATION, Vol. 10, No. 2: 91-118. (Persian)

Alaghband, A. (1389). General Management. Tehran: Ravan Publication.(Persian)

Ghasemi, B. (1388) Management of Organizational Behavior, Tehran: Sepahan Publication. (Persian)

Allen, N. J \& Meyer, J. P. (1991). The Measurement and Antecedents of Affective, Continuance and Normative Commitment to the Organization. Journal of Occupational Psychology, 63(1), 1-18.
Atkinson, T. N., \& Pilgreen, T. (2011). Adopting the Transformational Leadership Perspective in a Complex Research Environment. Research Management Review, 18(1), 42-63.

Avolio, B. J., Gardner, W. L., Walumbwa, F. O., Luthans, F., \& May, D. R. (2004). Unlocking the mask: A look at the process by which authentic leader's impact follower attitudes and behaviors. The Leadership Quarterly, 15(6), 801-823.

Avolio, B.J. (2005). Leadership Development in Balance: Made/Born. Mahwab, NJ: Erlbaum.

Begley, P.T. (2001), "In pursuit of authentic school leadership practices", International Journal of Leadership in Education, Vol. 4 No. 4, pp. 353-66

Belcourt,M., Bohlander, G., \& Snell, S (2008), “ Managing Human Resours". 5th Canadian Edition. Thomson-nelson.

Chen, C. C. (2010). The mediating effect of employees' experience of inclusion and the moderating effect of individual work values on the relationship of authentic leadership style and organizational commitment (Doctoral dissertation, Alliant International University, Marshall Goldsmith School of Management, San Diego).

Cohen-Charash, Y., \& Spector, P. E. (2001). The role of justice in organizations: A metaanalysis. Organizational behavior and human decision processes, 86(2), 278-321.

Cropanzano, R,. Molina, A. (2015). ORGANIZATIONAL JUSTICE. International Encyclopedia of the Social \& Behavioral Sciences, 2nd edition, Volume 17. 379-384.

Crow, M. M., Lee, B.C., joo, j. j., (2011) organizational commitment among South Korean police officer. An International journal of police strategies \& management. $35,402-423$

Elamin AM, Alomaim N. 2011. Does Organizational Justice Influence Job Satisfaction and Self-Perceived Performance 
in Saudi Work Environment, International Management Review,; 7(1): 38-49.

Emuwa, A. (2015). Examining the Endorsement of Authentic Leadership, Organizational Commitment, and Perceived Leader Effectiveness among Nigerian Employees (Doctoral dissertation, REGENT UNIVERSITY).

Gardner, W. L., Cogliser, C. C., Davis, K. M., \& Dickens, M. P. (2011). Authentic leadership1145. A review of the literature and research agenda. The Leadership Quarterly, 22(6), 1120-

Gelens, J., Dries, N., Hofmans, J., \& Pepermans, R. (2013). The role of perceived organizational justice in shaping the outcomes of talent management: A research agenda. Human Resource Management Review, 23(4), 341-353.

Goldman, B. \& Kemis, M. (2002). The role of authenticity in healthy psychological functioning and subjective well-being. Annals of the American Psychotherapy Association, 5, 18-20.

Karriker, J. H., \& Williams, M. L. (2009). Organizational justice and organizational citizenship behavior: Mediated multifocal model. Journal of Management, 35 (1): 112 125.

Kiersch, C. E. (2012). A multi-level examination of authentic leadership and organizational justice in uncertain times (Doctoral dissertation, Colorado State University).

Klein, H.J., Molloy, J.C., Brinsfield, C.T. ( 2012). Reconceptualizing workplace commitment to redress a stretched construct: revisiting assumptions and removing confounds. Academy of Management Review 37 (1), 130-151.

Klein, H.J., Park, H., (2015). Organizational Commitment. International Encyclopedia of the Social \& Behavioral Sciences, 2nd edition, Volume 17, 334-340.
Kwon, I. G. and Banks, D. W. (2004). Factors related to the organizational and professnal commitment of internal auditurs, managerial Auditing Journal, 19, 5, 606.220

Leroy, H,. Palanski, E, M,. Simons, T,. (2012). Authentic leadership and behavioral integrity as divvers of follower commitment and performance. Springer science business media B.V, 107: 255-264.

Meyer, J. P,. \& Herscovitch, L,. (2001). Commitment in the workplace: Toward a general model. Human Resource Management Review, 11, 299-326.

Philip PJ, Kumar R, Choudhary N. 2012. Relationship between Organizational Citizenship Behavior and Organizational Justice at Work Place, Proceeding Ninth AIMS International Conference on Management, January 1-4. 1215-1221.

Stewart Wherry, H. M. (2012). Authentic leadership, leader-member exchange, and organizational citizenship behavior: A multilevel analysis.

Tilstra, D, A. (2010). Charismatic leadership as Team leaders: An evaluation focused on pastoral leadership. Journal of Religious leadership9 (2), 27-52.

Walumbwa F.O., Wang P., Wang H., Schaubroeck J., Avolio B.J. ;( 2010) "Psychological processes linking authentic leadership to follower behaviors"; The Leadership Quarterly 21, pp.901-914.

Walumbwa, F. O., Avolio, B. J., Gardner, W. L., Wernsing, T. S., \& Peterson, S. J. (2008). Authentic leadership: Development and validation of a theory-based measuret. Journal of management, 34(1), 89-126

Owliyaee, Z. (1393). Exploring the relationship of four dimensions of organizational justice and organizational commitment among the staff of education in Tehran. M.A. thesis, Allame Tabataba'i University. 
Doosti, M., Amin Khatibi, and Ali-Asghar Khalili, (1392). The relationship between organizational justice and organizational commitment among the physical education organization of Mazandaran. Sports Management and Physical Sciences Research; year 3, 5: 59-71.

Abdullahi, Bijan, Gholam-Ali Yusselyani, and Jamal Hatamian (1393). The relationship between organizational justice and organizational commitment in elementary school teachers. NEW THOUGHTS ON EDUCATION, Vol. 10, No. 2: 91-118.

Alaghband, A. (1389). General Management. Tehran: Ravan Publication.

Ghasemi, B. (1388) Management of Organizational Behavior, Tehran: Sepahan Publication. 